\title{
Halina Sierocka
}

University of Bialystok

\section{CULTURAL DIMENSIONS OF LEGAL DISCOURSE}

\begin{abstract}
Despite the intention for precision and accuracy, legal discourse is oftentimes complex, archaic and ambiguous - which gives rise to contentious interpretation. Moreover, little or no attention is paid to the cultural dimension of legal discourse, which plays a critical role in the translation and interpretation of legal texts, as well as in the application of law. This paper endeavours to illustrate the impact the culture, or, more precisely, legal culture has on the way legal texts are construed or translated and to present problems which arise in the interpretation, translation and application of law as a result of cultural diversities.

Keywords: legal discourse, legal culture, interpretation, translation.
\end{abstract}

\section{Legal discourse across cultures}

Legal English (here also meant as legal discourse) with its distinctive features as accuracy, ambiguity, special terminology, complexity and conservatism (Jopek-Bosiacka, 2008) poses obstacles in translating, interpreting and applying legal texts. This complexity and uncertainty is deeply affected by religions, ethics, philosophy and culture of a particular nation (Northcott \& Brown, 2006). It is the culture that numerous scholars (like Duranti, 1997; Bhatia \& Bhatia, 2011) find crucial in the interpretation of legal discourse. Duranti (1997:277 as cited in Bhatia \& Bhatia, 2011) states that: "if we want to understand what people mean with, through, and sometimes despite their words, one must look beyond linguistic means ... meanings are seen as located not only in language, but in social values, beliefs, social relationships, and larger exchange and support systems, including family structure and the social organisation of the community".

Any culture (both social and professional), as Bhatia \& Bhatia (2011: 493) remark, shapes not only the way professional and disciplinary texts, and associated social actions are constructed and interpreted but also refers 


\section{Halina Sierocka}

to professional practices "in which these are embedded". Thus the interpretation of legal discourse, in his mind, should take into account the cultural contexts "in which it takes shape, is interpreted, used and exploited to achieve socio-political ends".

The impact that culture has on the interpretation of Legal English is not in doubt. Understanding legal culture (i.e. ideas, values expectations and attitudes towards law and legal institutions which some public or some part of the public holds" (Friedman, 1997:34) is a crucial factor which both affects translation and interpretation hence application of legal texts.

\section{Cultural dimension of legal discourse in translation}

The importance of culture in the translation of legal discourse cannot be underestimated. Even though many scholars ignore the fact that law is culture dependent, some (like Obenaus, 1995; Medrea \& Caraiman, 1997; Cornelius, 2011) recognise that there is a close link between law and culture, even emphasizing that "legal documents are pregnant with culture" (Obenaus, 1995:249). Those who recognise the importance of culture in legal discourse remark that the primary aim of legal translation is to create a set of parallel texts which are equal in legal effect from the source language to the target language in terms of authority, function and legal status of the translated text, legal system and cultural settings within of which the translated text will be read and/or used. Medrea \& Caraiman (1997) point out strongly that in fact the role and the task of the translator or interpreter of legal texts is not only "to translate words but legal systems" apart from other dilemmas like which trend to follow - this of simple Legal English terminology (i.e. so-called Plain English) or that which adores archaic Legal English, full of "hereinafter", "therewith" or "whatsoever". Nevertheless, it is a new cultural background, compared to the original that may perform a completely different function. Legal systems are expressions of culture and in multilingual societies or societies with diversified cultural histories translation of particular phrases or expressions may be a thorny dilemma for interpreters and translators as some concepts, notions or institutions may exist in the source culture, but not in the target culture. The examples from the Polish legal system include such words or concepts as zachowek or izba wytrzeźwien. They do not have equivalents in English as these institutions have not evolved in the common law system.

Zachowek is an institution which entitles the next of kin to receive half of the share the person normally would receive after the testator's death 
if no testament had been prepared even if the testator possibly had been against it. Some dictionaries (Merriam-Webster's Dictionary of Law 1996, for example) provide the definition which might seem close to the concept of zachowek i.e. legitime (or legitim) which is defined as "the portion of a testate succession that is reserved for a forced heir". This definition however is not a precise equivalent as zachowek is the right which is granted to any heir, not exclusively a forced one.

Izba wytrzeźwien is an institution which was established in 1956 as a part of the government programme to prevent and combat alcoholism and promote sobriety among Polish citizens. This institution, supported by the local government, is a place where people are brought for a night or a few hours if they are found drunk in public places. They are examined by a doctor, receive necessary medicines like sedatives if they are aggressive, can have a shower and are kept there until they get sober. Unlike other institutions of public order, its services are not free of charge therefore it is often informally described as "the most expensive hotel in the world" as the cost of service usually exceeds the price of one-day stay in a decent hotel (almost 100 Euros a day). One may find some translations of izba wytrzeźwień like detoxication ward or sobering-up station but the term is not precise and some more explanations are needed to describe it more accurately. The term "ward" in the detoxication ward may denote that it is a part of hospital, but in fact it is not. On the other hand, the definition of sobering-up station, apart from defining the concept, makes a reference to particular nationalities i.e. the Czech, the Russians and the Poles and hence exploits the intercultural dimension.

Obviously, interpreters and translators can use different techniques to compensate these lacks in the legal terminology in a particular legal system however these compensations would not be possible at all if translators and interpreters were not equipped with the knowledge, not only of special legal terminology but also of cultural and social contexts.

Apparently, to avoid ambiguity in translation and interpretation of law, Medrea \& Caraiman (1997) advocate the exploitation of dictionaries and glossaries of legal terms. Despite some constraints such as: lack of morphological or phonetic information (in glossaries), or too general character as far as content is concerned (a selection of terms from various law branches in dictionaries) or the fact that for one entry there might be diversified translations, which are scarcely disambiguated by their contextualization, they are still invaluable to circumvent confusion and equivocation in the translation of legal texts. This is due to citations which help readers to understand the translated term better as they express a word, phrase or a meaning 


\section{Halina Sierocka}

in authentic use (contextualization), the provision of sources for selecting headwords or the inclusion of quotations. The fact that glossaries despite their aforementioned deficiencies and lack of examples frequently indicate only one translation, is of much help as it consequently leaves no room for vagueness.

In conclusion, following Medrea \& Caraiman's opinion (1997:273), it can be stated undoubtedly that the translator's main task as a producer of the target text is to identify the connections between the two cultures in order to render a completely functional translation.

\section{Cultural dimension of legal discourse in the application and interpretation of legal texts}

The problems grounded in different cultural contexts and its influence on the interpretation and application of law are researched by abundant scholars in various settings. Hafner (2011), for instance, examined the impact of different legal cultures in international arbitration. He emphasizes that alternative dispute resolution process of international commercial arbitration is a perfect example of the context in which the participants of the said process represent various socio-cultural backgrounds and in which diversified national, commercial and legal cultures meet. What hinders the process of international arbitration it is the fact that it refers to both civil law and common law systems, which as both legal systems differ significantly, may pose problems as regards the interpretation of law and its application. The doctrine of 'precedent' is one of prime examples which distinguish civil law systems from common law systems. As Hafner (2011:118) points out, despite the fact that some attempts have been made to design international, commercial arbitration...

...to be a flexible procedure capable of accommodating a range of participants from diverse legal cultural backgrounds, including both civil law and common law traditions (...) international commercial arbitration remains a site of cultural contact with clear potential for problems in intercultural communication.

The consequences of diversified assumptions about the source of law and its application were, inter alia, differences in professional legal reasoning in the various traditions. In his study, Hafner (2011) wanted to research cultural variation in professional reasoning in arbitral awards (the reasoned decision of the arbitrator). His analysis was based on three principal sources of data: 
- small corpus of extracts of the International Chamber of Commerce (ICC) arbitration awards,

- structured interviews with arbitration practitioners, including arbitrators and counsel,

- professional publications and handbooks related to award writing.

Hafner (2011) examined the issue of cultural variation in professional reasoning comparing the common law awards and civil law awards. His study revealed that importance of reasoning in arbitration as such was acknowledged regardless of the legal backgrounds of the arbitrator and regardless of the aforementioned system of law. Cultural variations are however reflected in reasoning styles in the two legal traditions. The discourse of civil law awards reflects more deductive approach (legal rules tend to be efficiently stated, referenced and deductively applied) whereas common law awards provide more elaborate discussion of law, focusing on precedent cases and relying on direct quotation of sources. Finally, the exploitation of codeswitching in civil law awards (i.e. switching from the language of the arbitration, English, to the language of the applicable civil code, for example French or German) like in the sentence...

(5) Similarly, the Cour de Cassation, upholding a decision of Cour d'appel of Paris, affirmed that arbitral tribunal had jurisdiction... (Award 11876)

Court of Cassation Court of Appeal Hafner (2011:124)

...enables legal terms and concepts to be accurately identified and specified, confirms that arbitration practice is multicultural and multilingual, and must be flexible enough to satisfy the needs of parties from various legal cultures.

Another example of the case where legal cultures encounter is the case of a Polish citizen, Jakub T. who was found guilty of rape and of causing grievous bodily harm by the Crown Court in Exeter, England.

On 29 January 2008 Jakub T. was sentenced to life imprisonment for the crime of rape, with a recommendation that he should serve a minimum of nine years before he could be considered for parole. For the crime of causing grievous bodily harm, the defendant was sentenced to life imprisonment with a recommendation that he should serve a minimum of 6 years before he could apply for parole. With such verdicts, Jakub T. received two sentences of life imprisonment. Moreover, the British court decided that both sentences should be served simultaneously, and Jakub T. is not eligible to apply for parole before he has served nine years in prison.

On 22 July 2008, Jakub T. was transferred to Poland in order to serve his sentence of imprisonment. The District Court in Poznań issued a decision 


\section{Halina Sierocka}

which stated that the crimes for which Jakub T. had been sentenced are commensurable with the Polish legal provisions in Article 197 (1) of the Criminal Code and Article 156 (1) (2) of the Criminal Code, and that the sentences to be served in the Republic of Poland are the sentences of life imprisonment passed according to English law, and decided that Jakub T. is eligible to apply for parole on both sentences after he has served at least 9 years in prison.

According to Polish law, the maximum term for rape is 12 years imprisonment, whereas the crime of causing bodily harm is subject to a maximum of 10 years in prison. If the combined punishment was applied (something that is not possible under English law), Jakub T. could be sentenced to 12 years in prison and he could be released on parole after having served half of the sentence, i.e. after 6 years in prison. (Sierocka, 2011). Some questions may be posed in this context. Does the principle of mutual trust and recognition of judgements assumed in European Union law constitute a sufficient guarantee of a fair judgement of a Polish citizen by, for example, an English judicial system which is based on different legal culture? Which punishment should be imposed if penal law in each of the aforementioned countries stipulates different punishments for the same crime (yet arising from legal culture of a particular country)?

An interesting example of legal discourse across cultures is provided by Bhatia \& Bhatia (2011). They undertake the discussion on the role of cross-cultural, socio-political and ideological factors in the interpretation of law in Hong Kong. The case is grounded in some events in the history of this area i.e. the return of Hong Kong to the People's Republic of China and the creation of Hong Kong as a Special Administrative Region of the Peoples' Republic of China (HKSAR) - widely known as the 'One Country, Two Systems'. This historical event created particular context where three languages (English, Chinese, Cantonese), two cultures and two different legal systems (Hong Kong - common law system, China - civil law system) coexist, which all have posed and still pose a number of problems in the interpretation of rules and regulations in the translations of legal intentions. It is especially vivid in the Right of Abode Case presented by Bhatia \& Bhatia (2011:484-493). The case refers to the interpretation of specific sections of the Basic Law (the Government of Hong Kong 1990) (the law which is considered the mini-constitution of Hong Kong Special Administrative Region (HKSAR), which allowed the right of abode in Hong Kong to all those persons of Chinese nationality who were born outside of Hong Kong whose parents were permanent residents in Hong Kong. The Basic Law however did not stipulate whether there was an obligation for any of the parents to 
have had the status of permanent resident at the time of the child's birth. Before the power was transferred (i.e. before 1st July 1997) a large number of people from Hong Kong moved to mainland China and had children there. Their children did not have the right of abode in Hong Kong under the immigration laws prior to the handover. However, many of them moved to Hong Kong illegally and later they claimed their right of abode under the Basic Law. This controversial case went to the courts and the Courts of Final Appeal (Government of Hong Kong, Court of Final Appeal 1999), the highest court in HKSAR which stated that the right of abode in Hong Kong may be granted to the Chinese nationals if:

- they were born in Hong Kong before or after the transfer of sovereignty or

- they have resided in Hong Kong for a continuous period of not less than seven years before or after the handover or

- they were born outside Hong Kong to persons covered by the above two categories.

The interpretation of the Court of Final Appeal was quite broad and before long was challenged by the government and the legislating authority based in Beijing. The Beijing government actions (the government asked the Standing Committee of the National People's Congress to reinterpret the aforesaid articles, which effectively overturned the Court decision) resulted rather from the emerging socio-political context (social and economic problems due to massive inflow of eligible persons from mainland China into Hong Kong) than the wording of the aforementioned articles of the Basic Law itself. It again confirms the fact that to understand other people's intentions, one must take into account not only the meanings of the words, but also social values, beliefs and culture.

\section{Conclusions}

The aim of this paper was to offer some insights on the influence culture, or, more precisely legal culture, has on the process of translating, interpreting and applying legal texts. Despite the intention of legislators to produce unambiguous and accurate texts, particular changing cultural and social contexts (like country's system of government, legal system, historical and cultural values) make them more confusing when legal cultures and systems differ enormously from each other. Even though in some cases, specificity and complexity of language variety can be valued (as in the study of poetry) with reference to legal discourse it might be an impediment while interpreting, translating and applying law. 
Bhatia, V.K. \& Bhatia, A. (2011). Legal discourse across cultures and sociopragmatic contexts. World Englishes. Vol. 30 (4): 481-495. DOI: 10.1111/j. 1467-971X.2011.01727.

Cornelius, E. (2011). The curious case of legal translation. Liberator 32 (1):121143.

Duranti, A. (1997). Linguistic Antropology. Cambridge: Cambridge University Press.

Hafner, C. (2011).Professional reasoning, legal cultures, and arbitral awards. World Englishes. Vol. 30 (1), 117-128. DOI: http://dx.doi.org/10.1111/j.1467971X.2010.01691.x.

Jopek-Bosiacka, A. (2008). Przektad Prawny i Sadowy. Warszawa: Wydawnictwo Naukowe PWN.

Medrea, N. \& Caraiman, C. (2011). The problem of legal Romanian-English/English-Romanian dictionaries and glossaries and legal translations. Curentul Juridic, The Juridical Current, Le Courant Juridique Vol. 47, 269-274.

Northcott, J. \& Brown, G. (2006). Legal translator training: Partnership between teachers of English for legal purposes and legal specialists. English for Specific Purposes 25, 358-375.

Obenaus, G. (1995). The legal translator as information broker. In M. Morris (Ed.), Translation and the Law (pp. 247-259). Amsterdam: John Benjamins.

Sierocka, H. (2011). Legal English - Niezbędnik przysztego prawnika. Białystok: Publikator. 